\title{
CHARLES RONALD VAWDREY COUTTS
}

C. R. V. Coutrs died suddenly in the "Provident Mutual" office on 17 October 1938 at the age of 62 . He had recently returned from the actuarial conference in New York, and was just taking up again his usual daily work.

He was educated at Marlborough, and in 1895 at the age of 19 began his training for actuarial work under $\mathrm{H}$. C. Thiselton at the "Hand-inHand" office. Thiselton worked very hard himself, and expected his staff, mostly young beginners, to do the same, but in return he gave them ample opportunities to become acquainted with all aspects of life assurance work, and freely discussed its problems with them. Coutts qualified as a Fellow of the Institute of Actuaries in 1902, and by then had acquired a thorough grounding in life assurance practice.

He was appointed Assistant Actuary of the "National Mutual" in 1905, and passed with relief from the somewhat Spartan conditions of the "Hand-in-Hand" to the genial comradeship of Geoffrey Marks. He was with Marks for nine years, and from him learnt much of the art of management of a life office.

A greater degree of leisure enabled him to begin to make his mark at the Institute. He wrote two papers at this time, which were discussed at sessional meetings, one on Reversions in April 1906, and one on Bonus Reserve Valuations in December 1907. Although the opportunity to prepare these papers came to him from the less arduous conditions of work at the "National Mutual", it was his experience at the "Handin-Hand" which gave him his material. Reversions were one of Thiselton's enthusiasms, and Bonus Reserve Valuations had been made at the "Hand-in-Hand" for many years.

Coutts presented his material skilfully, with sound comments of his own. These papers brought him to the notice of senior actuaries, and as he was obviously a man of parts it was not long before he was asked to join in the work of the Institute. He was an examiner in 1908 and again in 1915, and he served on the Council from 1914 almost continuously until his death.

In I9I4 he became the chief officer of the "Provident Clerks" life office, and after the end of the War was mainly responsible for the rapid development of the new business of that office and its transformation into the "Provident Mutual" of to-day. He became especially interested in the investment of life assurance funds and submitted a paper on this subject to the Institute in January 1925, in which he maintained that the investments of a life office should be selected so as to correspond with its liabilities and advocated investment for a yield over a long period. In February 1926 he submitted a paper on the Distribution of Life Office Profits, pointing out that current systems of bonus distribution needed to be reviewed because a system which was equitable as between 


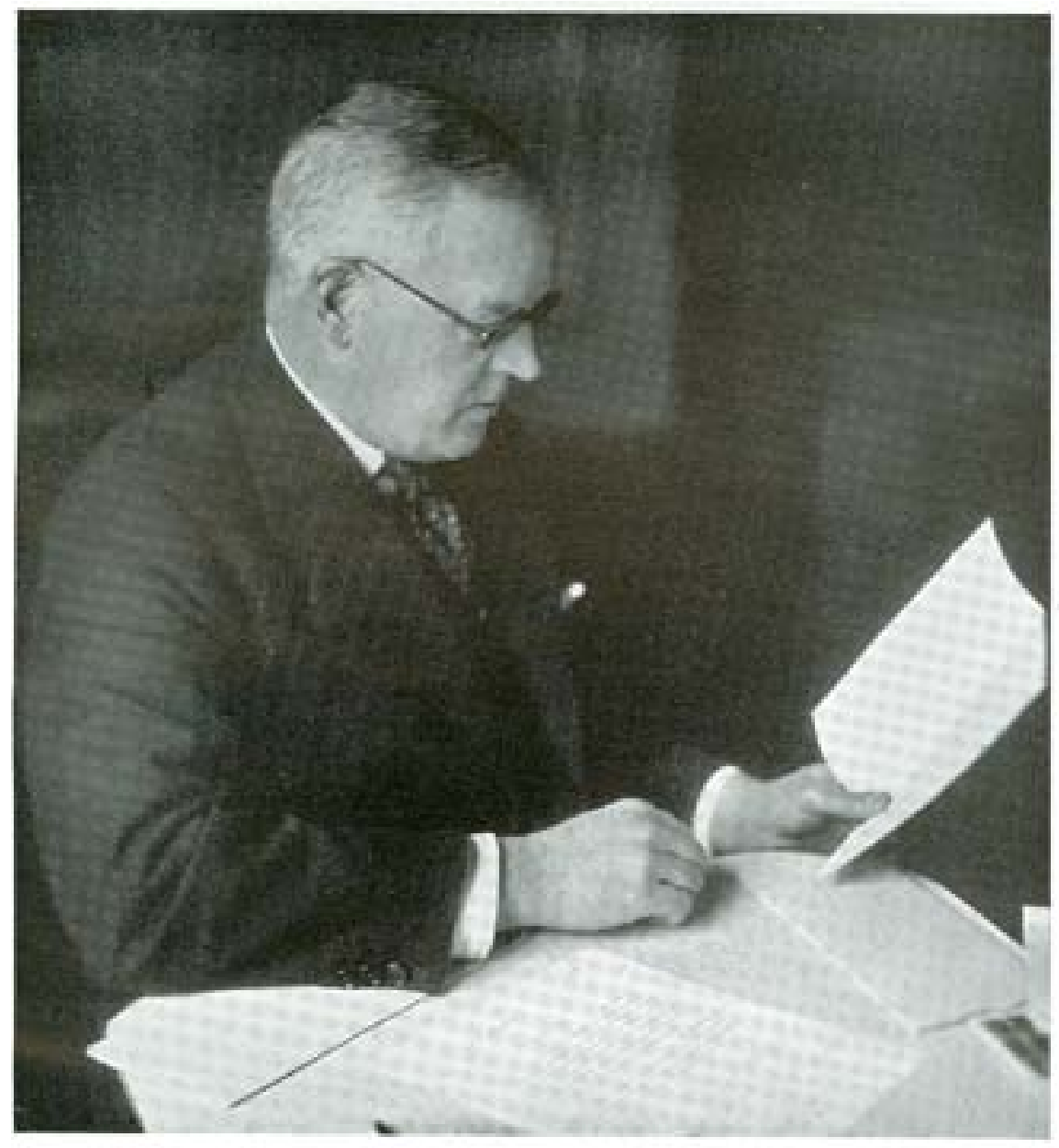

Charles Ronald Vawdrey Coutts

Facing p. 226 
different classes of policyholders before the War might have become inequitable in post-war conditions. It is a tribute to the quality of his papers that most of them have for considerable periods been included by the Council in the courses of reading recommended for actuarial students.

The post-war period also brought him increased responsibilities in connexion with the management of the affairs of the Institute. In 1920, when the examinations were being held twice a year, he returned to the Board of Examiners in the responsible position of Chairman. He was one of the Honorary Secretaries of the Institute from 1922 to I924, a Vice-President from 1924 to 1928 , and Treasurer from 1930 to 1932 .

During this period he became one of the leading members of the Institute, both at the Council Table and at the Sessional Meetings. Except for matters involving abstruse mathematics, there were few subjects brought up for discussion on which he did not form and express a decided opinion. He was a persistent critic, and gave his reasons for his opinions clearly and cogently. He was quick in repartee and delighted in controversy, frequently throwing out provocative remarks in order to stimulate discussion.

In 1934 he was given the honour of election to the Presidency of the Institute. At that time he was still in his second year as Chairman of the Life Offices' Association, but was apparently well able to carry the double burden, and discharged the duties of both offices until the end of their respective terms with the buoyant ease that was so characteristic of him.

At the Institute he had become disturbed at the amount of time and effort required from students before they could obtain the Fellowship, and the leading event of his Presidency was the appointment by the Council at his request of a Committee to review the whole examination and tuition system of the Institute. When the Committee found itself unable to recommend the specific remedy of specialization in the later parts of the Examinations, which he had advocated, it must have been a severe disappointment for him, but he welcomed the energy with which the Committee proceeded to develop the tuition system. The Institute owes him a special debt of gratitude for his insistence in 1935 that the time had come to make a thorough review of its Classes and Examinations. It was at his suggestion that the Committee entrusted with the task consisted mainly of younger members of the Council who, as he said, would be in charge of the affairs of the Institute when the men of his own age had left the scene.

We have lost, very suddenly, a man of courage and determination, a resolute fighter always ready to take up the cudgels on behalf of actuaries and their Institute, and any other cause in which he was interested, but for all his pugnacity a man with a warm heart for old friends and young actuaries.

H.B. 